\title{
Attribution Theory and Strategic Decisions on Organizational Success Factors
}

\author{
Professor Ben E. Akpoyomare Oghojafor \\ Department of Business Administration \\ University of Lagos, Lagos State, Nigeria \\ Olufemi Olabode Olayemi (Corresponding author) \\ Department of Business Administration \\ University of Lagos, Lagos State, Nigeria \\ Tel: +234-1-802-370-5627_ E-mail: femolayemi1@yahoo.com \\ Olukunle. O. Oluwatula \\ Department of Psychology, Redeemer's University \\ (RUN) RCCG City, Ogun- Nigeria \\ Tel: +234-1-802-370-5627_ E-mail: taluoshine@yahoo.com \\ Patrick Sunday Okonji \\ Department of Business Administration \\ University of Lagos, Lagos State, Nigeria \\ Tel: +234-1-803-578-9583_E-mail:patforward2000@yahoo.com
}

Received: August 20, 2011

Accepted: December 23, 2011 Published: February 15, 2012

doi:10.5430/jms.v3n1p32

URL: http://dx.doi.org/10.5430/jms.v3n1p32

\begin{abstract}
This study examines the pattern of attributions of managers in business organizations as they relate to strategic decisions on critical success factors including personnel, market leadership and customers' loyalty. A survey of 60 managers was conducted in Lagos, Nigeria and some psychological measures were administered to them. The results show that managers attribute strategic decisions on personnel, market leadership and customers' loyalty to effort, ability and nature of the task. Managers with personality traits of extraversion and conscientiousness show similar pattern of finding. The study concludes that inter causes of attributions principally serve as basis for strategic decision making. The implications of the study are also discussed.
\end{abstract}

Keywords: Strategic Management, Attribution, Extraversion, Conscientiousness, Critical Success Factors

\section{Introduction}

Research on psychological foundations of strategic management appears to have become a topical issue in the field of management. Strategic management may be described as the process of making critical decisions and going ahead to design some feasible actions in order to actualize the strategy of a business organization. For example, strategic management has been defined as "the set of decisions and actions that result in the formulation and implementation of plans designed to achieve a company’s objectives” (Pearce \& Robinson, 2003) such decisions go along way to create a dividing line between business organizations that are successful and those that are struggling to overcome liquidation. Since business organizations are in operation for profit maximization, it then becomes pertinent that they record success in their performance. This therefore calls for high quality and organization. Understanding strategic management rests 
on conceptualization of the term - strategy. Strategy, according to Cole (2004), involves creating a leading position for a business organization in the market by building positive perceptions in the sight of all stakeholders including the customers and the employees. Furthermore, strategy reveals a business organization's awareness of how, when, and where it should compete; against whom it should compete; and for what purposes it should compete (Pearce \& Robinson, 2003).

Johnson and Scholes (1997) offer two major characteristics of strategic decisions. They propose that a business organization is said to follow a long-term direction and also derive some competitive advantage when such organization operates on the framework of strategies. In practice, recruiting adequate number and quality personnel, winning customers' loyalty and becoming the market leader can be judged to be the results of long-term strategic decisions. Studies conducted on attributions considered issues involving academic success (Gipps \& Tunstall, 1998), formation of coalition members (Pearce \& DeNisi (1983), Supervisors' attribution (McFillen \& New, 1979), and Managerial cognition (Clapham \& Schwenk, 1991). However, they have neglected the attributions of critical success factors of any business organizations like quality and quantity of personnel, market leadership and customers' loyalty as examined in this study. This is the trust of the present study and therefore a major contribution to the field of strategic management with psychological foundations that was not commonly study in third world economies. Strategic decisions are very vital to organizational success as such contemporary managers must understand variables that are attributable to success. However, there is yet any study to relate attributions theory to strategic areas of business organizations like quality and quantity of personnel, market leadership and customers' loyalty. This formed the bases upon which the study examined psychological foundations as it relates to strategic management and organizational success. It examines the extent to which success in organizations is attributed to certain factors and as such the following objectives serve as a basis for this study.

Objectives of the study

The objectives of this study are as follows:

i. To examine what factors do mangers attribute to organizational success

ii. To appraise the extent to which quality personnel selection process assist in strategic decisions

iii. To evaluate factors that contributes to organizational success in attaining its goals.

iv. To investigate those areas of organization's activity that is significant to success.

\section{Theoretical Framework}

Attribution theory is one of several cognitive theories of motivation (typically grouped along with goal orientation, expectancy X value theory, and self-efficacy theory) Attribution theory originated with Julian Rotter and Fritz Heider's work and Wiener has further promoted it over the last thirty years (Weiner, 1972; Weiner, 2000). Attribution theory seeks to explain how an individual's perceived reasons for past success and failure contribute to their current and future motivation and success (Weiner, 1974b). The theory revolves around four causal attributions: ability, effort, task difficulty, and luck. Each is characterized as stable or unstable, internal or external, and controllable or uncontrollable (Weiner, 1986). The extent to which a person tends to use the same combination of these causes over time is known as attributional style (Metalsky \& Abramson, 1981).

"Self-enhancing," attributional styles are more motivational than "self-defeating” attributional styles. Nauta, Epperson, \& Waggoner (1999) explain that attributing the causes of one's successes to internal and stable factors and the causes of one's failures to external and unstable factors is self- enhancing, this way of thinking allows one to integrate positive outcomes into one's self-concept and exclude the integration of negative outcomes. Accordingly, the best attributional style would seem to be attributing success to one's abilities and failure to an external, uncontrollable factor such as luck. But this style turns out to be problematic because, as Covington and Omelich (1979) explain, some people believe that expending effort in order to achieve implies a lack of natural ability. A person doubting his or her abilities may choose not to expend effort, because it would demonstrate to others a lack of real ability. With this twist in mind, we turn the discussion to gender and engineering, where natural ability is paramount to a strong identity within the engineering culture (McIlwee \& Robinson, 1992).

According to Heider (1958), men behave as amateur scientists in social situations. He also asserted that, we generally explain behavior in two ways; either we attribute the behavior to a person or a situation. Attribution literally means a grant of responsibility. Albeit, the theory was first proposed by Heider (1958), later Jones (1972) and Harold Kelley (1967) developed a theoretical structure, which is now seen as an epitome of social psychology. The attribution theory by Heider (1958) divides the behavior attributes into two parts, external or internal factors. Internal attribution: When an 
internal attribution is made, the cause of the given behavior is within the person, i.e. the variables which make a person responsible like attitude, aptitude, character and personality. External attribution: When an external attribution is made, the cause of the given behavior is assigned to the situation in which the behavior was seen. The person responsible for the behavior may assign the causality to the environment or weather.

The theoretical framework adopted in this study was derived from attribution theory as propounded by Kelly. Attribution theory assumes that we can understand the why about others behavior. Thus, attribution has been defined as the "process by which an individual interprets events as being caused by a particular part of an environment” (Kelly, 1967). Kelly tried to explain the way people perceive internal and external attribution. He tried this, postulating the principle of co-variation. This model was known as Covariation Model. The basic principle of the covariation model states that the effect is attributed to one of the causes which co-varies over time. It also means that the behavior at various occasions varies. The covariation model considers three major types of information to make an attribution decision and to observe a person's behavior.

Kelly (1967) highlights that it is most likely to attribute another person's behavior to internal causes when conditions such as consensus and distinctiveness are low but consistency is high. On the other hand, it is most likely an individual's behavior will be attributed to external causes when the conditions of consensus, consistency and distinctiveness are all high. These three conditions are what Kelly regarded as sources of information when answering the question of why of behavior. But Kelly's covariation model has some limitations. The most prominent being that, it fails to distinguish between the intentional and unintentional behavior.

Weiner (1974, 1986) also developed a theoretical framework that has become a major research paradigm of social psychology. Attribution theory assumes that people try to determine why people do what they do, i.e., attribute causes to behavior. A person seeking to understand why another person did something may attribute one or more causes to that behavior. A three-stage process underlies an attribution: (1) the person must perceive or observe the behavior, (2) then the person must believe that the behavior was intentionally performed, and (3) then the person must determine if they believe the other person was forced to perform the behavior (in which case the cause is attributed to the situation) or not (in which case the cause is attributed to the other person).

Weiner (1986) focused his attribution theory on achievement. He identified ability, effort, task difficulty, and luck as the most important factors affecting attributions for achievement. Attributions are classified along three causal dimensions: locus of control, stability, and controllability. The locus of control dimension has two poles: internal versus external locus of control. The stability dimension captures whether causes change over time or not. For instance, ability can be classified as a stable, internal cause, and effort classified as unstable and internal. Controllability contrasts causes one can control, such as skill/efficacy, from causes one cannot control, such as aptitude, mood, others' actions, and luck. Attribution theory is closely associated with the concept of motivation

Weiner's theory has been widely applied in education, law, clinical psychology, and the mental health domain. There is a strong relationship between self-concept and achievement. Weiner (1980) states: "Causal attributions determine affective reactions to success and failure. This self-perception of reading ability reflects itself in children's expectations of success on reading tasks and reasoning of success or failure of reading. Similarly, students with learning disabilities seem less likely than non-disabled peers to attribute failure to effort, an unstable, controllable factor, and more likely to attribute failure to ability, a stable, uncontrollable factor. Lewis \& Daltroy (1990) discuss applications of attribution theory to health care. An interesting example of attribution theory applied to career development is provided by Daly (1996) who examined the attributions that employees held as to why they failed to receive promotions.

Attribution theory has been used to explain the difference in motivation between high and low achievers. According to attribution theory, high achievers will approach rather than avoid tasks related to succeeding because they believe success is due to high ability and effort which they are confident of. Failure is thought to be caused by bad luck or a poor exam, i.e. not their fault. Thus, failure doesn't affect their self-esteem but success builds pride and confidence. On the other hand, low achievers avoid success-related chores because they tend to (a) doubt their ability and/or (b) assume success is related to luck or to "who you know" or to other factors beyond their control. Thus, even when successful, it isn't as rewarding to the low achiever because he/she doesn't feel responsible, i.e., it doesn't increase his/her pride and confidence.

Principles:

1. Attribution is a three stage process: (1) behavior is observed, (2) behavior is determined to be deliberate, and (3) behavior is attributed to internal or external causes.

2. Achievement can be attributed to (1) effort, (2) ability, (3) level of task difficulty, or (4) luck. 
3. Causal dimensions of behavior are (1) locus of control, (2) stability, and (3) controllability.

Thus the working statements that served as guide for this study were:

1. It is expected based on the assumptions of this theory that the participants attribute causes of their decisions to either internal causes such as ability and effort, and external factors such as nature of the task, competitors' strategy and luck.

2. It is also expected that personality traits of extraversion and conscientiousness will serve as intervening variable to the attribution factors.

The present study adopted these working statements because the researchers were not set to test hypothesis. It, therefore, sought to provide answers to the questions what attributions would managers offer for strategic decisions on personnel quality and quantity, market leadership and customers' loyalty?, and what relationships exist between extraversion and conscientiousness personality traits and attributions of the managers on strategic management decisions?

\section{Methods}

Participants and Procedure: The study adopted a cross-sectional survey design and involved participants who were chosen on the basis of purposive sampling technique. The sample size was 60 which consisted of 19 males and 41 females. The sample included managers of corporate establishments and some had their individually-funded business organisations. The rationale for the inclusion of these participants that they were executives at the management levels who were involved in decision making of their organisations. Such decisions were specifically related to strategic issues like personnel, market share and customer loyalty. Their age ranged from 28 to 51 years with a mean of 37.03. The years of service ranged from 1 to 29 years. The managers were contacted at a distance learning centre by the researchers and the copies of the research instruments were handed over to each of them for their response. Instructions about how to attend to the instruments were clearly spelt out and good understanding was shown by the participants.

Research Instrument: The research instruments consisted of a paper and pencil questionnaire designed for the purpose of the study. This aspect of the instrument measures strategic management decisions on personnel quality and quantity, market leadership and customers' loyalty. Managers were asked to rate from 1(lowest) to 5(highest) their attributions of these management decisions to internal factors such as ability and effort, and external factors such as nature of the task, competitor's strategy and luck. Also, the participants were asked to indicate their age, years of service and educational status. Big-five personality scale was also adopted to measure the personality traits of the participants.

The Big-Five Personality Scale has 44 items and five subscales which include Extraversion, Agreeableness, Conscientiousness, Neuroticism and Openness. Only two traits - extraversion and conscientiousness - were adopted for this study and their mean scores were 26.83 and 28.30 respectively. The reliability coefficients for the B5 were provided by John, Donahue and Kentle, (1991). They are Cronbach Alpha, .80 and test-retest of .85. The B5 has convergent validity of .75 and .85 as reported by Costa \& McCrae (1992) and Goldberg (1992) respectively. Umeh (2004) provided the divergent validity coefficients of $.05, .13, .11, .39$ and .24 respectively for the five subscales administered on Nigerian sample.

\section{Results}

The results obtained in this study are as follows;

1. Managers' Attributions of strategic decisions on personnel, market leadership and customers' loyalty to ability, effort, nature of task, competitors' strategy and luck.

\section{Extraversion Personality Traits and Attributions of Managers.}

3. Conscientiousness Personality Trait and Attributions of Managers.

Table 1 show that $44.4 \%$ of managers who had low extraversion trait attributed personnel quality to ability and $38.9 \%$ of them to effort. On the other hand, managers with high extraversion attributed decision on personnel quality to effort (40.5\%) and ability (35.7\%). Table 2 indicates that 55.6\% of managers who had low extraversion trait attributed the number of personnel to the nature of the task and managers with high extraversion attributed decision on personnel quantity to the nature of the task also $66.7 \%$. In table 3 , it was observed that managers with low extraversion trait attributed customers' loyalty to effort (38.9\%) and ability (33.3\%). Managers that had high extraversion trait attributed customers' loyalty principally to effort (50\%).

Table 3 shows that managers with low extraversion trait attributed customers' loyalty to effort (38.9\%) and ability (33.3\%). Managers that had high extraversion trait attributed customers' loyalty principally to effort (50\%). Table 4 clearly shows that managers with low extraversion trait attributed market leadership to effort (50\%).While managers with high extraversion trait attributed market leadership to ability (33.3\%) and effort (31\%). 
While in table 5, the results show that managers with low conscientiousness personality trait attributed personnel quality to ability (66.7\%) and 33.3\% to effort. Managers who had high conscientiousness trait attributed personnel quality to effort (41.7\%) and ability (31.3\%). Table 6 it was evidently clear that managers with low conscientiousness attributed having adequate number of personnel to nature of task (58.3\%). Managers with high conscientiousness attributed having adequate number of personnel to nature of the task (64.6\%).

Whereas, table 7 revealed that majority of the managers with low trait of conscientiousness attributed customers' loyalty to effort (75\%) and managers with high trait of conscientiousness attributed customers' loyalty to effort (39.6\%). Table 7 shows that managers with conscientiousness attributed customers' loyalty to effort (75\%) as well as high conscientiousness managers (39.5\%). Table 8 shows that managers with low conscientiousness attributed market leadership to effort (50\%) while managers with high conscientiousness attributed market leadership to both ability and effort $33.3 \%$ each.

\section{Discussion}

This research work represents an application of attribution theory to strategic management decisions on critical success factors in any business organizations. The study was designed to answer two research questions. The first question was what attributions managers would offer for strategic decisions on critical success factors - personnel quality and quantity, market leadership and customers' loyalty. The second question was to find out the relationships that existed between two big-five personality traits - extraversion and conscientiousness - and the attributions of the managers on the three critical success factors. Extraversion as one of the big-five personality traits was chosen and measured as positive emotions. Conscientiousness was chosen and measured as goal directedness. These two measurement variables were assumed to be significant traits which if possessed by the managers could determine their attributions.

The pattern of findings revealed was similar in answering the two research questions. Majority of the managers attributed their decisions on personnel quality to effort, nature of task, market leadership to effort as well a s customers' loyalty. This pattern of result was repeated for the managers when they were divided along the line of extraversion and conscientiousness. The findings confirmed the predictions of the study as guided by the working statements adopted by the researchers. The results appear to be in this manner possibly because the managers were assumed to have positive emotions and had directions for their goals. A major finding was that the managers did not make any concrete attributions to luck. Could it be that the participants did not believe in luck? Further studies may be necessary in order to find out their perceptions about the place of luck in strategic management decisions.

\section{Conclusion}

In conclusion, the findings of this study do provide insights into the participants' views of causes of their strategic decisions on personnel, market leadership and customers' loyalty as they determine the success of business organizations. Managers that were studied attributed decisions in strategic areas of business activities as been influenced by positive emotions and goal oriented. Quality to effort, nature of task, market leadership to effort as well as customers' loyalty was seen as major variables that affect decisions on personnel. Though, the study reveals that managers do no make major contribution to luck in strategic decisions. It was observed that, an element of luck may not be totally ruled out since some times managers rely on gut feelings to take certain decisions based on past experiences. This study suggests further that in order to find out the perceptions of managers on place of luck, there is need to for strategic managers to evaluate those variables that are attributable to organizational success. The study had some limitations ranging from relatively small size survey sample, non-utilization of all the big-five personality traits to scanty of literatures in this area of research. And despite all, the study was able to contribute meaningfully to knowledge.

\section{References}

Clapham, S.E., and Schwenk,C.R., (1991). Self-Serving Attributions, Managerial Cognition and Company Performance, Strategic Management Journal 12(3) 219-229. http://dx.doi.org/10.1002/smj.4250120305

Cole, G.A. (2004). Management Theory and Practice, Thomson Learning, London $6^{\text {th }}$ edition

Costa, P. T., and McCrae, R.R. (1992). NEO PI-R. The Revised NEO Personality Inventory: Odessa FL: Psychological Assessment resources

Daly, D. (1996). Attribution Theory and the Glass Ceiling: Career Development Among Federal Employees. Public Administration \& Management: An interactive Journal

Gipps, C., and Tunsdall, P. (1998). Effort, ability and the teacher: Young children’s explanations for success and failure. Oxford Review of Education 24(2)) 149-165. 
Goldberg, L.R. (1992). The development of markers for the Big- Five factor structure. Psychological Assessment, 4 , 26-42. http://dx.doi.org/10.1037/1040-3590.4.1.26

Harvey, J.H., and Weary, G. (1985). Attribution: Basic Issues and Applications, Academic Press, San Diego.

Heider, F. (1958). The Psychology of Interpersonal Relations. New York: Wiley. http://dx.doi.org/10.1037/10628-000

John, O.P., Donahue, E. M., Kentle, R.L. (1991). The “Big-Five” Inventory - Versions 4a and 54. Berkeley: University of California, Berkeley Institute of Personality and Social Research.

Johnson, G., and Scholes, K. (1997). Exploring Corporate Strategy, Fourth Edition, Prentice Hall, New York.

Jones, E. E., Kannouse, D. E., Kelley, H. H., Nisbett, R. E., Valins, S., and Weiner, B., Eds. (1972). Attribution: Perceiving the Causes of Behavior. Morristown, NJ: General Learning Press.

Kelly, H.H. (1967). Attribution Theory in Social Psychology, Nebraska Symposium on Motivation

Lewis, F. M., and Daltroy, L. H. (1990). "How Causal Explanations Influence Health Behavior: Attribution Theory." In Glanz, K., Lewis, F.M. and Rimer, B.K. (eds.) Health Education and Health Behavior: Theory, Research and Practice. San Francisco, CA: Jossey-Bass Publishers, Inc

McFillen, J.M., and New, J.R. (1979). Situational determinants of attributions and behaviour. The Academy of Management Journal 22(4) 793-809. http://dx.doi.org/10.2307/255815

McIlwee, J., and Robinson, J. (1992). Women in engineering: gender, power, and workplace culture. New York: State University of New York Press.

Metalsky, G. I., and Abramson, L. Y. (1981). Attributional Styles: Toward a Framework for Conceptualization and Assessment. In P. C. Kendall \& S. D. Hollon (Eds.), Assessment Strategies for Cognitive-Behavioral Interventions. New York: Academic Press.

Miller, S. (1997). Implementing Strategic Decisions: Four Key Success Factors Organization Studies, Vol. 18, No. 4.

Nauta, M. M., Epperson, D. L., and Waggoner, K. (1999). Perceived causes of success and failure: Are women's attributions related to persistence in engineering majors? Journal of Research in Science Teaching, 36(6), 663-676.

Pearce II, J. A., and De Nisi, S.A. (1983). Attribution theory and strategic decision making: An application to coalition formation, The Academy of Management Journal Vol. 26 No.1 Pp 119-128. http://dx.doi.org/10.2307/256138

Pearce II, J.A., and Robinson, R.B. (2003). Strategic management: formulation, implementation, and control, McGraw Hill, Boston, 8th edition

Umeh, C.S. (2004). The impact of personality characteristics on student adjustment on campus. Unpublished Ph.D Research Monograph, Department of Psychology, University of Lagos.

Weiner, B., Frieze, I., Kukla, A., Reed, L, and Rosenbaum, R.S. (1971). Perceiving the causes of success and failure. NY: General Learning Press

Weiner, B., and Kukla, A. (1970). An attributional analysis of achievement motivation. Journal of Personality and Social Work Vol. 15 Pp 1-20, http://dx.doi.org/10.1037/h0029211

Weiner, B. (1972). Theories of Motivation: From Mechanism to Cognition. Chicago: Markham Publishing Company.

Weiner, B. (1974). Achievement motivation and attribution theory. Morristown, N.J.: General Learning Press.

Weiner, B. (Ed.). (1974b). Cognitive Views of Human Motivation. New York: Academic Press, Inc.

Weiner, B. (1986). An attributional theory of motivation and emotion. New York: Springer-Verlag.

Weiner, B. (1992). Human Motivation: Metaphors, theories and research. Newbury Park, CA: SAGE Publications.

Weiner, B. (2000). Intrapersonal and interpersonal theories of motivation from an attributional perspective. Educational Psychology Review, 12(1), 1-14. http://dx.doi.org/10.1023/A:1009017532121 
Table 1. Percentage distributions of managers with low and high extraversion and their attributions on personnel quality

\begin{tabular}{|c|c|c|c|c|c|c|c|}
\hline \multicolumn{7}{|c|}{ EXTRAV * PERSQUAL Cross tabulation } & \multirow{2}{*}{ Total } \\
\cline { 2 - 7 } & Ability & Effort & Task & Compstrategy & Goodluck & \\
\hline EXTRAV .00 Count \% within EXTRAV & $(8) 44.4 \%$ & $(7) 38.9 \%$ & $(1) 5.6 \%$ & (2) $11.1 \%$ & & $(18) 100.0 \%$ \\
\hline 1.00 Count \% within EXTRAV & $(15) 35.7 \%$ & $(17) 40.5 \%$ & $(8) 19.0 \%$ & (1) $2.4 \%$ & $(1) 2.4 \%$ & $(42) 100.0 \%$ \\
\hline Total Count \% within EXTRAV & $(23) 38.3 \%$ & $(24) 40.0 \%$ & $(9) 15.0 \%$ & (3) $5.0 \%$ & $(1) 1.7 \%$ & $(60) 100.0 \%$ \\
\hline
\end{tabular}

Table 2. Percentage distributions of managers with low and high extraversion and their attributions on number of personnel

\begin{tabular}{|c|c|c|c|c|c|c|}
\hline \multicolumn{7}{|c|}{ EXTRAV* PERSNO Cross tabulation } \\
\hline & \multicolumn{5}{|c|}{ PERSNO } & \multirow[t]{2}{*}{ Total } \\
\hline & Ability & Effort & Task & Comstrategy & Goodluck & \\
\hline EXTRAV .00 Count \% within EXTRAV & (5) $27.8 \%$ & (2) $11.1 \%$ & (10) $55.6 \%$ & (5) $5.6 \%$ & - & $(18) 100.0 \%$ \\
\hline 1.00 Count \% within EXTRAV & (3)7.1\% & (6) $14.3 \%$ & (28) $66.7 \%$ & (3) $7.1 \%$ & $24.8 \%$ & $(42) 100.0 \%$ \\
\hline Total Count \% within EXTRAV & (8) $13.3 \%$ & (8) $13.3 \%$ & (38) 63.3\% & (4) $6.7 \%$ & $23.3 \%$ & $(60) 100.0 \%$ \\
\hline
\end{tabular}

Table 3. Percentage distributions of managers with low and high extraversion and their attributions on customer's loyalty

\begin{tabular}{|c|c|c|c|c|c|}
\hline \multicolumn{6}{|c|}{ EXTRAV * CUSLOYAL Cross tabulation } \\
\hline
\end{tabular}

Table 4. Percentage distributions of managers with low and high extraversion and their attributions on market leadership

\begin{tabular}{|c|c|c|c|c|c|c|}
\hline \multicolumn{7}{|c|}{ EXTRAV* MKTLEAD Cross tabulation } \\
\hline & \multicolumn{5}{|c|}{ MKTLEAD } & \multirow[t]{2}{*}{ Total } \\
\hline & Ability & Effort & Task & Comstrategy & Goodluck & \\
\hline EXTRAV .00 Count \% within EXTRAV & (3) $16.7 \%$ & (9) $50.0 \%$ & (5) $27.8 \%$ & (1) $5.6 \%$ & - & (18) $100.0 \%$ \\
\hline 1.00 Count \% within EXTRAV & (14) $33.3 \%$ & (13) 31.0\% & (3) $7.1 \%$ & (8) $19.0 \%$ & (4) $9.5 \%$ & (42) $100.0 \%$ \\
\hline Total Count \% within EXTRAV & (17) $28.3 \%$ & (22) 36.7\% & (8) $13.3 \%$ & (9) $15.0 \%$ & (4) $6.7 \%$ & $100.0 \%$ \\
\hline
\end{tabular}

Table 5. Percentage distributions of managers with low and high conscientiousness and their attributions

\begin{tabular}{|c|c|c|c|c|c|c|}
\hline \multicolumn{7}{|c|}{ CON * PERSQUAL Cross tabulation } \\
\hline & \multicolumn{5}{|c|}{ PERSQUAL } & \multirow[t]{2}{*}{ Total } \\
\hline & Ability & Effort & Task & Compstrategy & Goodluck & \\
\hline CON .00 Count \% within CON & (8) $66.7 \%$ & (4) $33.3 \%$ & - & - & - & $(12) 100 \%$ \\
\hline 1.00 Count \% within CON & (15) $31.3 \%$ & (20) $41.7 \%$ & (9) $18.8 \%$ & (3) $6.3 \%$ & $12.1 \%$ & $(48) 100 \%$ \\
\hline Total Count \% within CON & (23) $38.3 \%$ & (24) $40.0 \%$ & (9) $15.0 \%$ & (3) $5.0 \%$ & $11.7 \%$ & $(60) 100 \%$ \\
\hline
\end{tabular}


Table 6. Percentage distributions of managers with low and high conscientiousness and their attributions on number of personnel

\begin{tabular}{|c|c|c|c|c|c|c|}
\hline \multicolumn{9}{|c|}{ CON * PERSNO Cross tabulation } & \multirow{2}{*}{ Total } \\
\cline { 2 - 7 } & Ability & Effort & Task & Comstrategy & Goodluck & \\
\hline CON .00 Count \% within CON & $(2) 16.7 \%$ & $(1) 8.3 \%$ & $(7) 58.3 \%$ & $(2) 16.7 \%$ & & $(12) 100 \%$ \\
\hline 1.00 Count \% within CON & $(6) 12.5 \%$ & $(7) 14.6 \%$ & $(31) 64.6 \%$ & $(2) 4.2 \%$ & $(2) 4.2 \%$ & $(48) 100 \%$ \\
\hline Total Count \% within CON & $(8) 13.3 \%$ & $(8) 13.3 \%$ & $(38) 63.3 \%$ & (4) $6.7 \%$ & $(2) 3.3 \%$ & $(60) 100 \%$ \\
\hline
\end{tabular}

Table 7. Percentage distributions of managers with low and high conscientiousness and their attributions on customers' loyalty

\begin{tabular}{|c|c|c|c|c|c|}
\hline \multicolumn{6}{|c|}{ CON * CUSLOYAL Cross tabulation } \\
\hline & \multicolumn{4}{|c|}{ CUSLOYAL } & Total \\
\cline { 2 - 5 } & Ability & Effort & Task & Comstrategy & \\
\hline CON .00 Count \% within CON & - & $(9) 75.0 \%$ & $(1) 8.3 \%$ & $(2) 16.7 \%$ & $(12) 100 \%$ \\
\hline 1.00 Count \% within CON & $(9) 18.8 \%$ & $(19) 39.6 \%$ & $(12) 25.0 \%$ & $(8) 16.7 \%$ & $(48) 100 \%$ \\
\hline Total Count \% within CON & $(9) 15.0 \%$ & $(28) 46.7 \%$ & $(13) 21.7 \%$ & $(10) 16.7 \%$ & $(60) 100 \%$ \\
\hline
\end{tabular}

Table 8. Percentage distributions of managers with low and high conscientiousness and their attributions on market leadership

\begin{tabular}{|c|c|c|c|c|c|c|}
\hline \multicolumn{9}{|c|}{ CON * MKTLEAD Cross tabulation } & Total \\
\cline { 2 - 7 } & Ability & Effort & Task & Comstrategy & Goodluck & \\
\hline CON .00 Count \% within CON & $(1) 8.3 \%$ & $(6) 50.0 \%$ & $(2) 16.7 \%$ & (1) $8.3 \%$ & $(2) 16.7 \%$ & $(12) 100 \%$ \\
\hline 1.00 Count \% within CON & $(16) 33.3 \%$ & $(16) 33.3 \%$ & $(6) 12.5 \%$ & $(8) 16.7 \%$ & $(2) 4.2 \%$ & $(48) 100 \%$ \\
\hline Total Count \% within CON & $(17) 28.3 \%$ & $(22) 36.7 \%$ & $(8) 13.3 \%$ & $(9) 15.0 \%$ & $(4) 6.7 \%$ & $(60) 100 \%$ \\
\hline
\end{tabular}

